\title{
Blended Learning as an Emerging Approach to Teacher Education in Higher Education in Sri Lanka: Lessons from a State-of-the-Art Review
}

\section{Manjula Vithanapathirana}

Professor in Educational Psychology, Faculty of Education, University of Colombo

ABSTRACT
Although blended learning in higher educat ion is well researched, the
emphasis on blended learning in teacher education is relatively limited.
Blended teacher education is an emerging approach within the State
higher education sector in Sri Lanka. This article presents a review of
empirical studies from recent global literature on blended learning in
teacher education in the higher education sector. The review addresses
three research questions: a) the nature of the research publications,
b) themes and sub-themes addressed in the studies and c) future
directions for the design of blended learning and research. With a
systematic protocol of selection and a set of inclusion and exclusion
criteria, 54 empirical research articles were selected as the sample for
this state-of-the-art review. Twenty-four countries were represented
in the sample. The majority of the articles were on pre-service teacher
education and the research design commonly used was quantitative. A
thematic analysis of the research articles identified six broad themes.
The discussion on each theme and its sub-themes provides lessons
from global research on blended learning and the transfer of knowledge.
Future research, if focused more on interventionist designs, would help
develop successful student-centered practices in blended learning for
teacher education within higher education.

\section{KEY WORDS:}

Blended learning, higher education, teacher education, state-of-theart, thematic analysis

Suggested Citation: Vithanapathirana, M. (2021). Blended learning as an emerging approach to teacher education in higher education in Sri Lanka: Lessons from a state-of-the-art review. University of Colombo Review (New Series III), 2(1), 61 - 78.

(C) 2021 The Authors. This work is licenced under a Creative Commons Attribution 4.0 International Licence which permits unrestricted use, distribution, and reproduction in any medium, provided the original work is properly cited. 


\section{Introduction}

Traditional face-to-face (F2F) instruction involves interactions between instructors and learners who are in the same physical location, whereas information and communication technologies (ICT) mediate online learning experiences and interactions without requiring learners and instructors to be F2F in the same location. On the other hand, traditional online or distance teacher training programs do not offer enough F2F interaction, either with an instructor or with colleagues who participate in the teacher training courses. In contrast, blended learning courses are developed and delivered with a selective combination of F2F human facilitation and online learning using digital technologies. Blended learning is, therefore, considered a pedagogy that uses the best attributes of both F2F and online modes to promote learning. The premise is that students and faculty should not view the F2F component of a blended course and the online element as separate components. Hrastinski (2019, p. 565) indicates that in blended learning, it is unusual to focus on either instruction or learning; instead, these are regarded as two sides of the same coin.

Blended learning is also considered by some authors as synonymous with hybrid learning (Bryan \& Volchenkova, 2016, p. 25). However, the term blended learning is more common. Although there are various debates about the definition of blended learning, one of the most accepted recent definitions is by Allen and Seaman (2010, p. 5). Accordingly, a course that blends online and F2F delivery with a substantial proportion of the content delivered online, which typically uses online discussions and has a reduced number of F2F meetings, is considered a blended learning course. Allen and Seaman suggest that, in blended learning, the proportion of content delivered online should be between $30 \%$ to $79 \%$. They also classify courses offering one percent to $29 \%$ online content, and which use a learning management system (LMS) or web pages to post syllabi and assignments, as web facilitated programs. If a course is delivered $80 \%$ online, it is considered an online course (p. 5).

Boelens et al. (2015) and Picciano (2009) emphasize the deliberate and planned combination of online and classroom-based interventions in defining the term blended learning, thus eliminating unintentional and random instances where the two modalities are combined. However, blended learning is not just adding F2F learning activities to online learning. It includes both asynchronous and synchronous online learning (Garrison \& Kanuka, 2004, p. 96). According to Perveen, "asynchronous environments provide students with readily available material in the form of audio/video lectures, handouts, articles and power point presentations. This material is accessible anytime anywhere" (cited in Amiti, 2020 , p. 63). Blended synchronous learning, on the other hand, is where "remote students participate in F2F classes by means of rich-media synchronous technologies such as video conferencing, web conferencing, or virtual worlds" (Bower et al. as cited in Hrastinski, 2019, p. 567).

Blended course design is considered a pedagogical transformation when students relearn how to learn, and teachers know how to teach in the new modality. Alammary et al. (2014, p. 443) classify blended learning course designs into three types: a) low-impact blend where extra activities are added onto an existing course, b) medium-impact blend 
where existing activities on a course are replaced, and c) high-impact blend where an entire blended learning course is designed from scratch. Further, the authors recommend that in the absence of a high level of technical support, a low-impact blend can be implemented although it may not allow for the maximum benefits of blended learning. It would, however, bring some benefits to the learning experience.

As in most countries where conventional teaching takes place, Sri Lanka has adopted the F2F modality for decades, where teacher educators and teacher trainees interact in person. However, as noted by Burns (2011), various models of distance teacher education used print, audio, tele-visual, multi-media and established web-based modules. In Sri Lanka, distance teacher education has also been a practiced modality for several decades mainly using printed modular material. Yet, planned blended learning teacher education models are a new concept, especially where conventional teacher education has been practiced for decades. The first planned blended teacher education program in Sri Lanka is currently being developed through the Contemporary Teaching Skills for South Asia project, popularly known as CONTESSA (Contessa, n. d.). Aimed at capacity building in teacher education, the project is co-funded by the Erasmus + program of the European Union and directed by the University of Graz in Austria and Dresden University of Technology in Germany. The University of Colombo and the Open University of Sri Lanka are the Sri Lankan partners in the project. This intervention comprises technology infrastructure needed for online teaching and capacity building of the faculty for online and blended course development, teaching, and assessment.

This review article aims at being a timely contribution to the teacher education sector as research on blended learning for teacher education in conventional higher educational classrooms is still at a preliminary stage. As teacher education is a specialized type of professional education, the review that follows focusses on blended learning in teacher education, rather than higher education in general.

\section{Objectives of the Review}

The following research questions underpin this review:

1. In the global literature reviewed, what were the frequencies of annual research publications, which countries did they originate from, what types of groups were focused upon, and what were the designs adopted in the empirical studies?

2. What are the themes, sub-themes, and conclusions of globally published research from 2016-2020, on blended learning in teacher education within higher education?

3. What are the conclusions these publications highlight, and what are their implications for planning and research on blended learning in teacher education within the higher education sector?

\section{Justification for a State-of-the-Art Review}

Grant and Booth (2009) present a typology of reviews inclusive of 14 types and associated methodologies. The type best suited for the purpose of compiling a review on blended learning in teacher education within higher education was found to be the state- 
of-the-art review, as this type addresses the most current issues on a topic. Such state-ofthe-art reviews on this topic are, however, somewhat scarce. Keengwe and Kang (2013), for instance, did publish a review of twenty-three empirical studies on blended learning in teacher education, using an activity systems analysis where teacher education programs were analyzed according to subject, object, tools, roles, community, and rules. However, this review, although informative, contained studies only up to 2011. Again, while a systematic review by Dyment and Downing (2020) titled "Online Initial Teacher Education" declared that the term "online" includes an online component whether the teacher education program is exclusively online or not, its main focus was not on blended learning. A rapid review, published by the University of Birmingham (Perry et al., 2020) also focused on the effectiveness of remote blended teacher education programs by comparing a control group as well as similar programs offered in different modes. Yet, its focus was also too narrow, as it fulfilled only an experimental comparison of specific programs. Therefore, a state-ofthe-art, more recent review focusing on blended learning in teacher education within higher education across the world is necessary to fill this gap.

\section{The Search Protocol}

The first point of selection of the sample for this review was based on the date of the publication. Empirical research literature from 1st January 2016 up to 1st November 2020 was retrieved, giving priority to publications of the last five years. The search drew on the ScienceDirect, ProQuest, Emerald, Taylor and Francis, ERIC (Education Resources Information Centre) and Google Scholar databases. The Mendeley search tool was also used to peruse the Mendeley web catalogue. Review, conceptual, and theoretical articles were not taken into consideration. The keywords used in the search were "blended or hybrid learning". The keywords for teacher education were "teacher education, teacher training or professional development", "preservice or prospective teachers" and "student or intern teachers or in-service", and various combinations of these key words were used. Search terms within each group were combined by means of a Boolean "OR". The two groups of search terms were combined by means of a Boolean "AND". In addition, studies on online learning were excluded by means of a Boolean "NOT". More articles were also gathered through snowball sampling carried out on the reference lists of the selected articles.

The decision to include or exclude an article was based on the information provided in the title, abstract, and conclusion. The search was further refined by selecting only those articles which (a) specifically focused on blended learning in teacher education in higher education contexts, (b) reported the results of empirical research, and (c) were available as full articles. Conference papers, dissertations, reports and book chapters were omitted. The references were managed with the Mendeley Reference Manager version 2.41.0.

\section{Findings and Discussion}

Fifty-four empirical studies were identified through the search, read, and thematically analyzed. Their findings were organized and are presented in this article according to the research questions. 


\section{Research Question 1: Frequency of Publication}

The first research question was aimed at discovering the frequencies of annual research publications, the countries from which they originated, the types of groups that were studied and the research designs adopted in the empirical studies.

It was found that there was an upward trend in the number of publications from 2016 to 2020 (Table 1), as the number of empirical studies on blended learning in teacher education in 2020 was approximately four times the number in 2016.

Table 1: Number of Empirical Research Studies Identified by the Search on Blended Learning in Teacher Education within Higher Education Contexts

(1st January 2016 to 1st November 2020)

\begin{tabular}{l|c|}
\hline Year of publication & $\begin{array}{c}\text { Number of empirical research studies published on } \\
\text { blended learning in teacher education }\end{array}$ \\
\hline 2016 & 5 \\
\hline 2017 & 8 \\
\hline 2018 & 6 \\
\hline 2019 & 13 \\
\hline 2020 up to 1st November & 22 \\
\hline Total & 54 \\
\hline
\end{tabular}

Articles identified through the search were from 24 countries. The highest number of articles per country was 11, from Indonesia. Five articles were selected from the USA, Turkey, and Spain respectively. Three articles each were selected from Hongkong and Malaysia. The number produced by the other 18 countries was less than three. Two each were identified from Russia, Nigeria, South Africa, and Finland, and one each was selected from Thailand, Ireland, Vietnam, Australia, Mongolia, Philippines, Austria, India, Netherlands, Egypt, Denmark, Switzerland, Japan, and Iran.

As Table 2 indicates, the detected research articles focused mostly on preservice training. Research on in-service training comprised half of that number. One article focused on both modalities. There was also one research article each on cooperating teachers who are senior teachers helping in the teaching practicum of trainees, and on teacher educators.

Table 2: Blended Learning Research on Teacher Education within Higher Education by Target Group

\begin{tabular}{l|c}
\hline Year & Target groups focused on for research \\
\hline Pre-service & 34 \\
\hline In-service & 17 \\
\hline Both & 1 \\
\hline Cooperating senior teachers & 1 \\
\hline Teacher educator & 1 \\
\hline Total & 54 \\
\hline
\end{tabular}

Table 3 provides a summary of the research designs adopted in the studies identified by the search. The most prevalent type was the quantitative design, the majority of which were perception surveys. Mixed methods studies were also evident - a positive sign considering the emerging nature of this research area. Experimental comparisons with 
traditional models were also popular. Action research and design-based research which blend empirical and theoretical designs, and are interventionist, were fewer in number. A quick response research by Lockee (2020) highlights the importance of studying stories of teachers during the rapid shift to blended modes during the COVID-19 crisis.

Table 3: Research Designs

\begin{tabular}{l|c|}
\hline Research Design & Number of empirical research papers published \\
\hline Quasi-experimental & 8 \\
\hline $\begin{array}{l}\text { Non-experimental Post-test only } \\
\text { survey }\end{array}$ & 3 \\
\hline Case study & 2 \\
\hline Quantitative & 15 \\
\hline Mixed methods & 11 \\
\hline Qualitative & 11 \\
\hline Design based & 2 \\
\hline Action research & 1 \\
\hline Quick response research & 1 \\
\hline Total & 54 \\
\hline
\end{tabular}

\section{Research Question 2: Themes}

The second research question was on the themes highlighted in the studies on blended learning in teacher education within higher education. Accordingly, a thematic analysis of the selected 54 empirical research articles was carried out. Six broad themes were arrived at which are given in Table 4. They are: instructional designs, specialized courses and programs, teaching practicum, learner satisfaction and positive perceptions, program quality, and challenges and negative outcomes. The sub-themes of each of these themes were also identified.

Table 4: Themes and Subthemes of the Selected Research Articles under Review

\begin{tabular}{ll|l|}
\hline Key theme & Sub-themes \\
\hline 1. & Instructional designs & $\begin{array}{l}\text { Flipped classroom, learning management systems } \\
\text { (LMS), personalized learning and planning for } \\
\text { differentiation, MOOCs }\end{array}$ \\
\hline 2. & $\begin{array}{l}\text { Specialized courses and } \\
\text { programs }\end{array}$ & $\begin{array}{l}\text { Subject specific blended teacher education programs for } \\
\text { different subject oriented professional development }\end{array}$ \\
\hline 3. & Teaching practicum & $\begin{array}{l}\text { Mentoring, virtual internship, technology integrated } \\
\text { microteaching }\end{array}$ \\
\hline 4. & $\begin{array}{l}\text { Learner satisfaction and } \\
\text { positive perceptions }\end{array}$ & $\begin{array}{l}\text { Satisfaction about courses and strategies, positive } \\
\text { perceptions, self-efficacy, motivation, readiness }\end{array}$ \\
\hline 5. & Program quality & $\begin{array}{l}\text { Positive course and program outcomes, development } \\
\text { of communities of practice, 21st Century skill } \\
\text { development }\end{array}$ \\
\hline 6. & Challenges and negative & $\begin{array}{l}\text { Issues of digital competence of trainees, learner } \\
\text { expressed challenges }\end{array}$ \\
\hline
\end{tabular}




\section{Theme 1: Blended Learning Instructional Design}

Under this theme of blended learning instruction design, four subthemes were identified. They are a) flipped instruction b) learning management systems (LMS) based blended learning c) personalized learning and d) scaled-up blended learning interventions with massive open online course (MOOC).

Flipped Instruction: Flipped instruction is a form of blended learning with a reversed instructional strategy of a traditional lecture-based teaching model. Its objective is to improve the quality and efficiency of the teaching and learning process. One of the two articles on flipped instruction (Kurt, 2017) reports on a study in which the flipped approach was introduced at a higher education institution in Turkey. The flipped method incorporated asynchronous video lectures and active, group-based problem-solving activities in the classroom. The effectiveness of this flipped instruction was measured against a traditionally taught class. Quantitative and qualitative data from 62 preservice teachers revealed that a higher level of self-efficacy beliefs and better learning outcomes had prevailed for the experimental group in the flipped classroom, when compared to the control group in the traditional classroom.

The other study (Weinhandl et al., 2020), was a grounded theory qualitative analysis which analyzed expert views on professional mathematics and STEM teacher development through flipped classroom approaches. Here the interview data indicated that, the varying characteristics of different teachers affected their learning activities in relation to their professional development, including on adopting flipped instruction for mathematics and STEMs.

Learning Management System (LMS) based Blended Learning: Moodle is a learning management system (LMS) that is open source, can be obtained free of charge, and can be developed according to the needs of the users. Higher education programs adopt LMSs for a range of purposes and the use of LMS for teacher education is one. An experimental study conducted in Indonesia revealed that the use of the Moodle blendedlearning model in elementary school teacher education students during the COVID-19 pandemic was an effective solution to the challenges of social distancing (Rachmadtullah et al., 2020). Another study from Indonesia by Rasmitadila et al. (2020) confirmed the same. However, it was pointed out that unstable internet connections posed problems.

A comparative study between traditional and LMS based blended courses for inservice primary teacher trainees in Mongolia indicated that the implementation of blended learning can improve the quality of teacher education (Jachin \& Usagawa, 2017). A study of physics in-service teachers in the Russian Federation also revealed that LMS based blended learning was effective (Krasnova \& Shurygin, 2019). Hidayat et al. (2019) also reported a positive finding in a course in which the LMS was integrated with a Google classroom.

A study conducted in Australia (Holmes \& Prieto-Rodriguez, 2018) on LMS based teacher education, where data were collected through a survey and interviews with both undergraduate and postgraduate students, revealed a range of findings. They rated positively, the flexibility of access to materials on LMS, the good quality of short audio recordings of lectures, and proper organization. However, differences were found between student and 
staff views on the accessibility of online materials, with students rating its contribution to their learning more highly than staff. The two groups held similar views, however, with regard to the effectiveness of LMS tools enabling interactivity. Other studies by Vaishnav and Singh (2019), Evans et al. (2020) and Ndlovu and Mostert (2018) also confirmed that LMS mediated teacher education programs were more effective than traditional models.

Although LMS related pedagogy has yielded positive outcomes, it is necessary to analyze more deeply whether these programs can be classified as blended learning programs, or technology enhanced programs as differentiated by Allen and Seaman (2010).

Personalized Learning and Planning for Differentiation: Personalization is where students make instructional choices as opposed to teachers customizing instruction for students. The latter is referred to as differentiation. Personalization is an element in instructional design. Arnesen et al. (2019) present an intervention for personalized learning in blended learning. During the personalized blended learning intervention, the trainees realized the importance of personalization and emphasized its necessity in their future practice. However, it was also noted that for those students accustomed to passive learning, getting used to personalized learning can be very difficult. The study recommended that preservice teachers should, therefore, be gradually introduced to concepts and skills related to using technology in personalized learning within blended learning. It also differentiated between personalized learning software and adaptive learning software, where in the latter, the software makes choices on behalf of the student, based on performance.

Blended learning planned for differentiated learning was also highlighted by Mamman et al. (2019). This study examined the effectiveness of the station rotation model in a blended collaborative learning environment to improve pre-service teachers' critical thinking skills. The model allows learners to rotate between online learning and other learning modalities, following a fixed schedule, at the teachers' discretion. The experiment was conducted with 54 in each group, and results of the study showed that, in terms of critical thinking skills, there was a significant difference between the mean scores of those who followed a conventional approach and those who adopted the station rotation model. The latter group scored high in critical thinking skills.

\section{Massive Open Online Courses (MOOCs) in Scaling-up Blended Learning}

Interventions: The design and development of a MOOC, which can massively scale up access to a validated model of learning, shows the possibility of also scaling up a blended learning intervention. Gynther (2016) developed a design framework for a MOOC that complements blended learning. The design framework was used to develop in-service courses for teacher professional development.

\section{Theme 2: Specialized Blended Learning Teacher Education}

Specialized teacher education programs offered through blended learning is increasing. The studies on which this review is based included specialized programs for physical education (Calderón et al., 2020); secondary education (Arnesen et al., 2019); elementary teacher education (Rachmadtullah et al., 2020); vocational education (Dharma \& Rohendi, 2019); sustainability skills for teaching sustainability (Chin et al., 2019); 
English (Arifani et al., 2019; Farani, 2019; Islam et al., 2018; Koç, 2016; Yağc1 et al., 2016); visual literacy (Huilcapi-Collantes et al., 2020); mathematics (Ihechukwu et al., 2017, Islam et al., 2018; Nami et al., 2020; Ubah et al., 2020; Weinhandl et al., 2020; Yurniwati \& Yarmi, 2020); physics (Krasnova \& Shurygin, 2019); science education (Lee et al., 2016; Y1lmaz \& Malone, 2020); inclusive education (Vaishnav \& Singh 2019); music education (Hietanen \& Ruismäki, 2017; Tuisku \& Ruokonen, 2017); literature (Eutsler, 2018), computer assisted language learning (Nami et al., 2020); accounting education (Suyatmini et al., 2020) and multiple specializations (Karimi \& Ahmad, 2020).

It is encouraging to note that blended learning is adopted for teacher education programs in such a range of subjects including STEMs, humanities, and social sciences as well as professional subjects in education.

\section{Theme 3: Blended Learning and the Teaching Practicum}

The third theme was on blended learning adopted in the teaching practicum. The sub-themes arising out of this theme were: a) blended mentoring b) virtual internships and c) microteaching integrated with technology.

Blended Mentoring during the Teaching Practicum: Supervision of the teaching practicum is a critical component in teacher education. Buatip et al. (2019) report on a study of technology integrated mentoring which was helpful for managing workloads, and face-to-face and virtual collaborative supervision. It saved travel time in relation to visiting schools regularly because feedback was received through text, image and video posts, chatting, and messaging. The supervisors, field mentors, and pre-service science teachers who were the focus group of this study had been involved in the blended mentoring process during a four-month teaching practicum. The outcome had been positive.

Virtual Internship: Theelen et al. (2020) revealed that pre-service teacher trainees experienced significantly less anxiety on following a virtual internship course. Trainees had reported that they were able to obtain a realistic understanding of teaching and felt better prepared for its practice as a result of the virtual internship course. The training provision of learning from videos of authentic classroom events, had resulted in good preparation for the actual professional teaching context. The results of this study implied that virtual internships can be a useful asset in teacher education.

Microteaching Integrated with Technology: Blended learning activities are effective in promoting student teachers' teaching skills in a blended micro-teaching context. Microteaching is a key experience that provides students with opportunities to practice teaching skills in an authentic environment. Albhnsawy \& Aliweh (2016) examined the impact of integrating a blended learning program into a microteaching course that was offered to student teachers in science education. The conclusion of the study was that combining synchronous and asynchronous activities and applications offered student teachers plenty of opportunities to receive feedback and exchange views. A blended learning micro-teaching course was, therefore, more effective for micro-teaching. 


\section{Theme 4: Learner Satisfaction, Motivations and Self-Efficacy}

Studies on satisfaction and positive perceptions adopted a range of research designs such as large scale surveys (Byrka, 2017; Yağc1 et al. 2016); experimental design (Kurt, 2017); case study (Chin et al., 2019; Shand \& Farrelly, 2018; mixed methods (Holmes \& Prieto-Rodriguez, 2018; Luisa \& Panes, 2019; Ubah et al., 2020); and a qualitative approach (Ndlovu \& Mostert, 2018; Weinhandl et al., 2020). According to Yağc1 et al. (2016) there was no significant difference across variables like gender, age, and year of study with regard to the perceptions of students on blended learning.

The positive features commonly acknowledged by teacher trainees on blended learning included flexibility of access, ICT based self-education, personalized learning, the balance between F2F and online components, the importance of online components which facilitated increased engagement, independence in learning and development of information literacy skills, and the appealing appearance of the LMS.

Kurt's (2017) study was on preservice trainees' motivation in the flipped, as compared to the traditional lecture-based classroom. The trainees had preferred the flipped classroom because it encouraged more active participation. A factor that led to improved motivation was, enjoyment of the flipped class model when watching videos prior to in-class meetings which had helped them learn the material better and was more enjoyable than assigned reading. Research studies by Suma et al. (2020), Eutsler (2018), and Sugiharto et al. (2019) also showed that learner readiness and motivation were high in blended programs on teacher education.

A quasi-experimental mixed method study (Knaggs et al., 2017) measured the selfefficacy of preservice elementary teachers in science education before and after a training, where the course was delivered in two different formats - face-to-face and hybrid with a $50 \%$ combination. The pre-and post-course self-efficacy of students in the two different course formats were thereafter compared. The qualitative data showed that participants attributed their increased levels of personal efficacy to the hands-on components of the course, as well as perceived positive teacher attitudes toward science, both of which were attributed to the hybrid format of the program.

The above studies illustrate, therefore, high satisfaction, motivation, readiness, and efficacy in learners following blended learning teacher education programs. This is encouraging for the future of blended learning for teacher professional development. Further studies on the quality of learning should be carried out to ascertain the effectiveness of each program. However, learner satisfaction can already be the basis for the development of blended courses and programs. It is also necessary to inquire into the ideal proportion of the online and face-to-face components of these programs.

\section{Theme 5: Quality of Blended Learning}

The quality of blended teacher education programs in the higher education sector was a focus in several of the studies. Arifani et al. (2019) revealed that blended professional training targeting English trainee teachers' creativity had positively influenced their teaching effectiveness. Independent learning and material variables showed the strongest influences. 
Ho et al. (2016) conducted a comparative study on the effectiveness of blended teacher education versus traditional programs and found that blended learning was more effective due to its flexibility, cost effectiveness, ability to improve interaction and teacher networks, and the involvement of administrators, instructors and school leaders.

Vaishnav and Singh (2019) conducted a study on the effectiveness of blended learning in inclusive education and revealed that it had better outcomes than traditional teacher education programs in this particular field. Martín-Martínez et al. (2020) in an evaluation of a blended learning program, revealed five factors for establishing a good model of blended teaching and learning. These included student expectations of their subjects, the use of web 2.0 tools, feedback from teachers, collaborative work with fellow classmates, and social relations among students themselves and with their professors.

Blended professional learning communities along with structured professional learning activities were found to have assisted teacher educators in shifting their professional identity from a curriculum deliverer to a curriculum maker (Widodo \& Allamnakhrah, 2020, p. 410). According to Trust and Horrocks (2017), the teachers who followed a blended teacher education program had also been able to develop a blended community of practice.

On a multi-dimensional skills scale for the 21st Century (Şentürk, 2020), the preservice teachers who had followed a blended learning program had shown a significant level of achievement in contrast to trainees who had followed traditional programs. A study by Murai and Muramatsu (2020) also illustrated that blended learning developed creative learning in teacher trainees. The discussion under this theme highlights, therefore, the effectiveness of blended learning programs in teacher education. This should encourage planners of teacher education programs to adopt this approach. However, challenges to blended learning should also be kept in mind.

\section{Theme 6: Challenges and Negative Outcomes}

One of the main challenges encountered in blended teacher education is the poor digital competence of trainees (Guillen-Gamez et al., 2020). Several studies illustrated this problem. Islam et al. (2018) reported that trainees expressed the need for furthering their skills regarding the online learning portal. Weinhandl et al. (2020) pointed out the need, as reported by the trainees, for a variety of high-quality learning materials on digital learning.

The other serious challenge was in relation to instructional design. Chan's (2019) research was carried out with 261 preservice student teachers who participated in a blended learning teacher education program. Data was collected through questionnaires and focus group interviews. The purpose was to understand student perceptions on blended learning and examine how the interaction between traditional and constructivist concepts influenced learning. The results indicated that the participants preferred face-to-face lectures over blended learning. The author's explanation for these findings was that the student teacher sample was rooted in a Confucian culture. A similar finding, that pre-service teachers viewed face-to-face training as more effective, was observed in a different context by Pardede (2019). 
A study on online mentoring within a blended teaching practicum had also yielded negative outcomes (Koç, 2016). The lack of opportunities for interaction with the faculty, when compared with a fully face-to-face teaching practicum, had posed difficulties to both trainee teachers and cooperating teachers who assist with practicum supervision. The trainee teachers had complained of their isolation due to the lack of opportunities to meet their supervisors. The supervisors also indicated that the overload of paper work and irregular attendance of trainee teachers posed problems. It is to be noted here that if proper planning and scheduling are not included in such programs, negative outcomes are likely.

Although such adverse outcomes are not many, lessons from each of them are important in order to make suitable improvements when planning blended learning courses for teacher education. It would be advisable to consider the recommendation of Alammary et al. (2014, p. 451) for incremental experimentation with blended learning, depending on the levels of familiarity with technology. Incremental knowledge on how technological media can be integrated into the traditional face-to-face experience to better meet student needs can help teachers gain more confidence. It would also avoid the high risk entailed of plunging straight into a high impact blended learning model.

\section{Research Question 3: Implications for Planning and Research}

This state-of-the-art review illustrates that blended learning has the potential to improve teacher education. A range of lessons from other contexts can be drawn upon when introducing blended learning teacher education programs, especially in conventional faculties and departments of teacher education in Sri Lanka. This review drew on research studies conducted in 24 countries, showing the wide popularity of the model in many different contexts. The increasing number of publications over the past five years (2016 to 2020) on the topic also indicates that blended learning in teacher education within higher education is an attractive option to consider when deviating from F2F models. As Bryan \& Volchenkova (2016, p. 28) highlight, however, it is necessary to study how to design effective blended learning courses for teacher education given the number of options for blending. As this review has revealed, blended learning has many optional design frameworks with varying impacts. Therefore, issues such as the suitability of structure, design and facilitation depending on varying contexts, the professional capacities of teacher educators, the ICT competence of trainees, and internet facilities should be considered.

In order to understand the range of possible outcomes of blended learning for teacher education, it is recommended, therefore, that a deeper analysis of each study be undertaken, considering the context and structure of the courses using Alammary's (2014) classification on the degrees of blending.

One of the most important gaps in the research reviewed, was the lack of focus on assessment in blended leaning for teacher education. There was not even a single study identified by the search on innovative assessment strategies in teacher education within a blended environment. Yet other areas that require further research if blended teacher education programs are to be sustainable are, needs of faculty, faculty development, time commitment of faculty and infrastructure (Evans et al., 2020). In-terms of research designs, 
more mixed methods studies should also be carried out towards a balanced perspective of the findings (Karimi \& Ahmad, 2020).

As the COVID 19 pandemic has disrupted education worldwide, the design of learning solutions has become a critical task. Although research can take many foci, it would be better if more empirical studies focusing on more interventionist designs are conducted. This would help develop successful designs and practices of blended learning with better strategies for student-centered learning. Ultimately this would benefit all blended learning courses and programs in teacher education within the higher education sector.

\section{References}

Alammary, A., Sheard, J., \& Carbone, A. (2014). Blended learning in higher education: Three different design approaches. Australasian Journal of Educational Technology, 30(4), 440-454. https://doi.org/10.14742/ajet.693

Albhnsawy, A. A., \& Aliweh, A. M. (2016). Enhancing student teachers' teaching skills through a blended learning approach. International Journal of Higher Education, 5(3). https://doi.org/10.5430/ijhe.v5n3p131

Allen, I. E., \& Seaman, J. (2010). Class differences: Online education in the United States 2010. The Sloane Consortium.

Amiti, F. (2020). Synchronous and asynchronous e-learning. European Journal of Open Education and E-learning Studies, 5(2), 60-70.

Arifani, Y., Khaja, F. N. M., Suryanti, S., \& Wardhono, A. (2019). The influence of blended in-service teacher professional training on EFL teacher creativity and teaching effectiveness. 3 L: Language, Linguistics, Literature, 25(3), 126-136. https://doi.org/10.17576/3L-2019-2503-10

Arnesen, K. T., Graham, C. R., Short, C. R., \& Archibald, D. (2019). Experiences with personalized learning in a blended teaching course for preservice teachers. Journal of Online Learning Research, 5(3), 251-274. https://www.learntechlib.org/primary/p/210637/

Boelens, R., Van Laer, S., De Wever, B., \& Elen, J. (2015). Blended learning in adult education: Towards a definition of blended learning. http://hdl.handle.net/1854/LU-6905076

Bryan, A., \& Volchenkova, K. N. (2016). Blended learning: Definitions, models, implications for higher education. Bulletin of the South Ural State University Series "Education. Education Sciences, " 8(2). https://doi.org/10.14529/ped160204

Buatip, S., Chaivisuthangkura, P., \& Khumwong, P. (2019). Enhancing science teaching competency among pre-service science teachers through blended-mentoring process. International Journal of Instruction, 12(3), 289-306. https://doi.org/10.29333/iji.2019.12318a

Burns, M. (2011). Distance education for teacher training: Modes, models, and methods. Education Development Center, Inc.

Byrka, M. F. (2017). Blended learning strategy in teacher training programs. Information Technologies and Learning Tools, 62(6), 216-223. 
Calderón, A., Scanlon, D., MacPhail, A., \& Moody, B. (2020). An integrated blended learning approach for physical education teacher education programmes: Teacher educators' and preservice teachers' experiences. Physical Education and Sport Pedagogy.

https://doi.org/10.1080/17408989.2020.1823961

Chan, E. Y. M. (2019). Blended learning dilemma: Teacher education in the Confucian heritage culture. Australian Journal of Teacher Education, 44(1), 36-51.

https://doi.org/10.14221/ajte.2018v44n1.3

Chin, C. K., Munip, H., Miyadera, R., Thoe, N. K., Ch'ng, Y. S., \& Promsing, N. (2019). Promoting education for sustainable development in teacher education integrating blended learning and digital tools: An evaluation with exemplary cases. Eurasia Journal of Mathematics, Science and Technology Education, 15(1). em 1653. https://doi.org/10.29333/ejmste/99513

Contemporary Teaching Skills for South Asia (n.d). https://contessa-project.eu/

Dharma, A., \& Rohendi, D. (2019). Implementation of blended learning in vocational teacher professional education. Advances in Social Science, Education and Humanities Research, 299, 123-126. https://dx.doi.org/10.2991/ictvet-18.2019.26

Dyment, J. E., \& Downing, J. J. (2020). Online initial teacher education: A systematic review of the literature. Asia-Pacific Journal of Teacher Education, 48(3), 316-333.

https://doi.org/10.1080/1359866X.2019.1631254

Eutsler, L. (2018). Blended literature discussions increase preservice teachers' enthusiasm for teaching reading. Journal of Literacy and Technology, 19(2). 128-153.

http://www.literacyandtechnology.org/uploads/1/3/6/8/136889/jlt_v19_number_2_winter18_ eutsler.pdf

Evans, J. C., Yip, H., Chan, K., Armatas, C., \& Tse, A. (2020). Blended learning in higher education: Professional development in a Hong Kong university. Higher Education Research and Development, 39(4). 643-656. https://doi.org/10.1080/07294360.2019.1685943

Farani, R. (2019). Blended learning approach implementation: Pre-service English teachers' perception. Advances in Social Science, Education and Humanities Research, 353, 95-100. https://dx.doi.org/10.2991/icosihess-19.2019.15

Garrison, D. R., \& Kanuka, H. (2004). Blended learning: Uncovering its transformative potential in higher education. Internet and Higher Education, 7(2), 95-105.

https://doi.org/10.1016/j.iheduc.2004.02.001

Grant, M. J., \& Booth, A. (2009). A typology of reviews: An analysis of 14 review types and associated methodologies. Health Information and Libraries Journal, 26(2), 91-108. https://doi.org/10.1111/j.1471-1842.2009.00848.x

Guillen-Gamez, F. D., Mayorga-Fernández, M. J., \& Del Moral, M. T. (2020). Comparative research in the digital competence of the pre-service education teacher: Face-to-face vs blended education and gender. Journal of E-Learning and Knowledge Society, 16(3), 1-9. https://doi.org/10.20368/1971-8829/1135214 
Gynther, K. (2016). Design framework for an adaptive MOOC enhanced by blended learning: Supplementary training and personalized learning for teacher professional development. The Electronic Journal of E-Learning, 14(1), 15-30.

Hidayat, M. L., Prasetiyo, W. H., \& Wantoro, J. (2019). Pre-service student teachers' perception of using google classroom in a blended course. Humanities and Social Sciences Reviews, 7(2), 363-368. https://doi.org/10.18510/hssr.2019.7242

Hietanen, L., \& Ruismäki, H. (2017). The use of a blended learning environment by primary school student teachers to study music theory. The European Journal of Social and Behavioural Sciences, 19(2), 2393-2404. https://doi.org/10.15405/ejsbs.212

Ho, V. T., Nakamori, Y., Ho, T. B., \& Lim, C. P. (2016). Blended learning model on hands-on approach for in-service secondary school teachers: Combination of e-learning and face-to-face discussion. Education and Information Technologies, 21(1), 185-208.

https://doi.org/10.1007/s10639-014-9315-y

Holmes, K. A., \& Prieto-Rodriguez, E. (2018). Student and staff perceptions of a learning management system for blended learning in teacher education. Australian Journal of Teacher Education, 43(3), 21-34. https://doi.org/10.14221/AJTE.2018V43N3.2

Hrastinski, S. (2019). What do we mean by blended learning? TechTrends, 63(5), 564-569. https://doi.org/10.1007/s11528-019-00375-5

Huilcapi-Collantes, C., Martín, A. H., \& Hernández-Ramos, J. P. (2020). The effect of a blended learning course of visual literacy for in-service teachers. Journal of Information Technology Education: Research, 19, 131-166. https://doi.org/10.28945/4533

Ihechukwu, B., Olunna, A., \& Raymond, U. (2017). Effect of blended learning on pre-service teachers' achievement in Mathematics: A case for sustainable teacher education. European Journal of Education Studies, 3(10), 572-582. https://doi.org/10.5281/zenodo.1038397

Islam, S., Sukri, A., Yunus, M. M., \& Yunus, M. (2018). Revitalising English teacher education through blended learning: A boon or bane? International Journal of Engineering and Technology, 97-101. https://doi.org/10.14419/ijet.v7i4.21.21623

Jachin, N., \& Usagawa, T. (2017). Potential impact of blended learning on teacher education in Mongolia. Creative Education, 8. 1481-1494. https://doi.org/10.4236/ce.2017.89104

Karimi, L., \& Ahmad, T. B. T. (2020). Perceived learning and satisfaction in a blended teacher education program: An experience of Malaysian teacher trainees. Contemporary Educational Technology, 4(3). https://doi.org/10.30935/cedtech/6103

Keengwe, J., \& Kang, J. J. (2013). A review of empirical research on blended learning in teacher education programs. Education and Information Technologies, 18(3), 479-493.

https://doi.org/10.1007/s10639-011-9182-8

Knaggs, C. M., Sondergeld, T. A., \& Henry, D. (2017). Science self-efficacy of preservice teachers in face-to-face versus blended environments. School Science and Mathematics, 117(1-2), 27-33. https://doi.org/10.1111/ssm.12204 
Koç, E. M. (2016). A critical look at a blended English language teacher education program with an emphasis on the practicum. International Review of Research in Open and Distributed Learning, 17(4). 66-81. https://doi.org/10.19173/irrodl.v17i4.2286

Krasnova, L., \& Shurygin, V. (2019). Blended learning of physics in the context of the professional development of teachers. International Journal of Emerging Technologies in Learning, 14(23), 17-32. https://doi.org/10.3991/ijet.v14i23.11084

Kurt G. (2017). Implementing the flipped classroom in teacher education: Evidence from Turkey. Journal of Educational Technology and Society, 20(1), 211-221. https://doi.org/10.2307/jeductechsoci.20.1.211

Lee, Y. C., Lau, K., \& Yip, V. W. Y. (2016). Blended learning for building student-teachers' capacity to learn and teach science-related interdisciplinary subjects. Asian Association of Open Universities Journal, 11(2), 166-181. https://doi.org/10.1108/aaouj-09-2016-0029

Lockee, B. B. (2020). Shifting digital, shifting context: (re)considering teacher professional development for online and blended learning in the COVID-19 era. Educational Technology Research and Development, 69, 17-20. https://doi.org/10.1007/s11423-020-09836-8

Luisa, L., \& Panes, D. (2019). Dimensions of learners' satisfaction in the delivery of instruction in blended learning program in teacher education institutions. PEOPLE: International Journal of Social Sciences, 4(3), 865-881. https://doi.org/10.20319/pijss.2019.43.865881

Mamman, B., Nihra Haruzuan Bin Mohd Said, M., \& Binti Ismail, Z. (2019). The immersion of blended learning and pedagogical approaches to enhance pre-service teacher critical thinking skills in Nigeria. Man in India, 98(3-4), 395-423. https://www.researchgate.net/publication/333236403

Martín-Martínez, L., Sainz, V., \& Rodríguez-Legendre, F. (2020). Evaluation of a blended learning model for pre-service teachers. Knowledge Management and E-Learning, 12(2). 147-164. https://doi.org/10.34105/j.kmel.2020.12.008

Murai, Y., \& Muramatsu, H. (2020). Application of creative learning principles within blended teacher professional development on integration of computer programming education into elementary and middle school classrooms. Information and Learning Science, 121(78). 665-675.

https://doi.org/10.1108/ILS-04-2020-0122

Nami, F., Marandi, S., \& Sotoudehnama, E. (2020). Experiencing collaborative professional development in a blended CALL teacher education course. Quarterly of Iranian Distance Education Journal, 2(2), 31-40.

Ndlovu, M. C., \& Mostert, I. (2018). Teacher perceptions of Moodle and Throughput in a blended learning program for in-service secondary school mathematics teachers. Africa Education Review, 15(2), 131-151. https://doi.org/10.1080/18146627.2016.1241667

Pardede, P. (2019). Pre-service EFL teachers' perception of blended learning. Journal of English Teaching, 5(1), 1-14. https://doi.org/10.33541/jet.v5i1 
Perry, T., Findon, M., Braim, B., Davison, I., Whatmore, T., Cottle, D., Anbreen, N., Cordingley, P., \& Crisp, B. (2020). Teacher education modality rapid review - Modes, affordances and evidence on remote and blended initial and continuing teacher education. University of Birmingham.

Picciano, A. G. (2009). Blending with purpose: The multimodal model. Journal of Asynchronous Learning Network, 13(1), 7-18. https://doi.org/10.24059/olj.v13i1.1673

Rachmadtullah, R., Subandowo, M., Rasmitadila, M., Humaira, M., Aliyyah,R., Samsudin, A. \& Nurtanto, M. (2020). Use of blended learning with Moodle: Study effectiveness in elementary school teacher education students during the COVID-19 pandemic. International Journal of Advanced Science and Technology, 29(7), 3272-3277.

https://www.researchgate.net/publication/341724918

Rasmitadila, R., Widyasari, W., Humaira, M., Tambunan, A. R. S., Rachmadtullah, R., \& Samsudin, A. (2020). Using blended learning approach (BLA) in inclusive education course: A study investigating teacher students' perception. International Journal of Emerging Technologies in Learning, 15(2). https://doi.org/10.3991/ijet.v15i02.9285

Şentürk, C. (2020). Effects of the blended learning model on preservice teachers' academic achievements and twenty-first century skills. Education and Information Technologies.

https://doi.org/10.1007/s10639-020-10340-y

Shand, K. \& Farrelly, S. G. (2018). The art of blending: Benefits and challenges of a blended course for preservice teachers. Journal of Educators Online, 5(1).

http://dx.doi.org/10.9743/JEO2018.15.1.10

Sugiharto, B., Corebima, A. D., Susilo, H., \& Ibrohim. (2019). The pre-service biology teacher readiness in blended collaborative problem based learning (BCPBL). International Journal of Instruction, 12(4), 113-130. https://doi.org/10.29333/iji.2019.1248a

Suma, K., Suwindra, I. N. P., \& Sujanem, R. (2020). The effectiveness of blended learning in increasing prospective physics teacher students' learning motivation and problem-solving ability. JPI, 9(3). https://doi.org/10.23887/jpi-undiksha.v9i3.21947

Suyatmini, S., Sari, D. E., \& Jatmika, S. (2020). Blended learning in teacher professionalism training program (PPG): A case study. International Journal of Scientific and Technology Research, 9(4), $2267-2272$.

Theelen, H., Willems, M. C., van den Beemt, A., Conijn, R., \& den Brok, P. (2020). Virtual internships in blended environments to prepare preservice teachers for the professional teaching context. British Journal of Educational Technology, 51(1), 194-210. https://doi.org/10.1111/bjet.12760

Trust, T., \& Horrocks, B. (2017). 'I never feel alone in my classroom': Teacher professional growth within a blended community of practice. Professional Development in Education, 43(4), 645-665. https://doi.org/10.1080/19415257.2016.1233507

Tuisku, V., \& Ruokonen, I. (2017). Toward a blended learning model of teaching guitar as part of primary teacher training curriculum. The European Journal of Social \& Behavioural Sciences, 20(3), 2520-2537. https://doi.org/10.15405/ejsbs.222 
Ubah, I. J. A., Spangenberg, E. D., \& Ramdhany, V. (2020). Blended learning approach to mathematics education modules: An analysis of pre-service teachers' perceptions. International Journal of Learning, Teaching and Educational Research, 19(7), 298-319. https://doi.org/10.26803/ijlter.19.7.17

Vaishnav, R. \& Singh, J. (2019). Effectiveness of blended learning for teaching inclusive education to teacher training. Blended Learning and Inclusive Education, 8(1), 1-9.

Weinhandl, R., Lavicza, Z., \& Houghton, T. (2020). Designing online learning environments for flipped approaches in professional mathematics teacher development. Journal of Information Technology Education: Research, 19. 315-337. https://doi.org/10.28945/4573

Widodo, H. P., \& Allamnakhrah, A. (2020). The impact of a blended professional learning community on teacher educators' professional identity: Towards sustainable teacher professional development. Journal of Education for Teaching, 46(3), 408-410.

https://doi.org/10.1080/02607476.2020.1761249

Yağcı, H., Çınarbaş, H. İ., \& Hoş, R. (2016). Turkish EFL students' perceptions about blended English courses in a teacher education programme. International Journal of Social Sciences and Education Research. 2(3), 774-784.

Yılmaz, Ö., \& Malone, K. L. (2020). Preservice teachers' perceptions about the use of blended learning in a science education methods course. Smart Learning Environments, 7(18).

https://doi.org/10.1186/s40561-020-00126-7

Yurniwati, Y., \& Yarmi, G. (2020). Promoting prospective teachers' conceptual knowledge through web-based blended learning. Journal of Research and Advances in Mathematics Education, 5(2), 187-201. https://doi.org/10.23917/jramathedu.v5i2.10418 